\title{
JAUNŲ ŽMONIŲ SAVIŽUDYBIŲ FENOMENO DISKURSAS
}

\author{
Birutė Strukčinskienė ${ }^{1}$, Dileta Tervydyte் $\dot{e}^{1,2}$, Vaiva Strukčinskaite் ${ }^{2}$, Neringa Strazdiene் $\dot{e}^{1}$, \\ Emilija Griškonytè ${ }^{4}$, Sigitas Griškonis ${ }^{1,3}$ \\ ${ }^{1}$ Klaipédos universitetas, ${ }^{2}$ Vilniaus universitetas, ${ }^{3}$ Klaipédos universitetine ligonine, \\ ${ }^{4}$ Lietuvos sveikatos mokslu universitetas
}

Raktažodžiai: savižudybès, fenomenas, jauni žmonès, jaunimas.

\section{Santrauka}

Lietuva jau keletą metų yra tarp šalių, kurios lyderiauja pagal savižudybių skaičių Europoje ir pasaulyje. Savižudybè - viena pagrindinių jaunų žmonių mirties priežasčiu mūsų planetoje. Jauno žmogaus gyvenime kyla daug iššūkių, kurie lemia jaunimo elgsenos kaitą. Šio darbo tikslas buvo jaunų žmonių savižudybių fenomeno analizè. Taikyta sisteminè mokslinès literatūros bei dokumentų apžvalga ir analizè.Savižudybè - tai ne liga, o desperatiškas jauno žmogaus, neradusio kitos išeities, poelgis. Savižudybe dažniausiai nèra staigus vienos priežasties nulemtas veiksmas. Tai paprastai būna procesas, kurio metu žmogus išgyvena vis didejantị stresą, emocinị skausmą, jausmų ir minčių sumaištị, o jo gebejjimas ìveikti krizę vis mažèja. Ši procesą dažniausiai užbaigia koks nors ịvykis ilgoje nesėkmių, stresinių įvykių grandinejje. Jaunų žmonių savižudybių priežastys ir rizikos veiksniai gali būti ịvairūs - socialiniai, asmeniniai, psichologiniai, sveikatos ir kt. Pastaruoju metu virtuali erdve, ypač interneto socialiniai tinklai tampa aktualiu jaunų žmonių savižudybių rizikos veiksniu. Jaunų žmonių savižudybės yra viena iš pagrindinių problemų, kurias spręsti reikia taikant efektyvias prevencijos priemones. Visuomenès informuotumo didinimas, savižudybès tabu laužymas ir švietimas, nukreiptas prieš vyraujančius mitus, galètų padèti užkirsti kelią šiems tyčiniams sužalojimams. Visuomenei reikètų suteikti daugiau informacijos, kaip atpažinti galimą savižudišką elgesị ir interpretuoti suicidinių minčiu turinčio jaunuolio siunčiamus pagalbos ieškojimo, siekiamo palaikymo, žinios skleidimo ženklus. Svarbu kurti ir įgyvendinti išsamias nacionalines strategijas, kurios padètų išvengti jaunimo savižudybių. Psichikos sveikatos stiprinimo programų igyvendinimas ir savalaikès pagalbos paslaugų prieinamumo vaikystès laikotarpiu didinimas turi tapti prioritetine sveikatos politikos sritimi.

\section{Ivadas}

Lietuva išsiskiria didžiausiu savižudybių rodikliu Europoje ir jau nemažai metų yra pirmajame valstybių penketuke pagal mirtingumą nuo savižudybių pasaulyje. Lietuvoje kasmet nusižudo daugiau kaip 1000 žmoniu, t. y. dvigubai daugiau nei metinis eismo įvykių skaičius. Suicidas yra ypač paplitęs tarp paauglių, jaunų suaugusiųų ir darbingo amžiaus žmonių [1]. Lietuvos suicidiškumo rodikliai yra beveik dvigubai didesni už pateikiamą pasaulio statistiką [2].

Savižudybė yra viena pagrindinių 15-24 metų jaunų asmenų mirties priežasčių pasaulyje [3]. Jaunų žmonių gyvenime kyla daug iššūkių (konfliktai, egzaminų baimè, psichinè ittampa, patyčios, nelaiminga meilè, tèvų skyrybos, patirti sunkūs ịvykiai ir asmeninès traumos, patirta seksualinè prievarta ar fizinis, emocinis smurtas ir kt.), kurie daro įtaką žmogaus psichinei sveikatai ir lemia elgsenos kaitą. Moksliniai tyrimai rodo, kad gausesnè trauminè patirtis siejasi su didesne suicidinio elgesio tikimybe. Taigi egzistuoja tam tikras slenkstis ar rodiklis, atspindintis žmogaus gebejjimą atlaikyti tam tikrą sudètingų įvykių keliamą ịtampą [4].

Savižudybès fenomenas yra pražūtingas individui, šeimai ir visai visuomenei. Jauni žmonès - visuomenès ateities garantas, todèl jų gerovès užtikrinimas yra svarbus valstybės uždavinys. Plačioji visuomenè ir sveikatos priežiūros specialistai dažnai stengiasi suprasti savižudybès fenomeną, kuris išlieka tabu daugelyje kultūrų [5]. Tačiau vis daugiau mokslinių tyrimų patvirtina, kad savižudybè ir savižudiškas elgesys skirtingose kultūrose gali būti skirtingai apibrèžiami, turèti skirtingą prasmę ir juos gali lemti skirtingos aplinkybès. Vien atskirų rizikos veiksnių ir jų sąsajų su savižudybių dažniu skaičiavimai labai mažai tepadeda suprasti žmonių savižudiško elgesio intenciją [6]. Todèl savižudybių prevencija turi būti daugialype ir apimti įvairius sektorius. Dažnėjančios jaunų asmenų, netgi paauglių, savižudybės 
- rimtas signalas atsakingiau kalbėti apie suicido reiškinị, santūriau vertinti sprendimą pasitraukti iš gyvenimo prièmusius žmones, ypač žinomus ir populiarius visuomenèje [7]. Jaunų žmonių savižudybės reiškinio tyrimai, mitų griovimas, informuotumo, supratimo, suvokimo didinimas, žinių apie ši fenomeną platinimas igalintų mažinti tokių tragedijų aukų skaičių ir padètų jauniems žmonėms pasirinkti gyvenimą, o ne mirtį.

Darbo tikslas - atlikti jaunų žmonių savižudybès fenomeno analizę.

\section{Tyrimo metodika}

Taikyta sisteminè mokslinès literatūros bei dokumentu apžvalga ir analizè.

\section{Rezultatai}

Savižudybės reiškinys. Savižudybės reiškinys jau daugelị metų laikomas svarbia visuomenès sveikatos problema ir yra viena iš pagrindinių mirties priežasčių pasaulyje. Nepaisant taikytų prevencijos strategijų, savižudybių skaičius per pastaruosius dešimtmečius ženkliai nepasikeitė [8]. Kiekvieno žmogaus aplinkoje yra asmenų, daugiau arba mažiau nukentejjusių, ịvykus savižudybei. Turbūt yra nedaug žmonių, kurių nepaliete mylimojo, draugo, kolegos ar paciento sprendimas nutraukti savo gyvenimą. Šių tragedijų ìvyksta visose šalyse ir ịvairiose kultūrose; tai gali nutikti bet kurioje šeimoje, įskaitant ir mūsų pačių [9].Nagrinèjant šiame straipsnyje aptariamą temą, savižudybė apibrěžtina ne kaip liga, bet kaip desperatiškas jauno žmogaus, neradusio kitos išeities, poelgis. Nusižudyti gali tiek psichikos ligoniai, tiek sveiki, bet nesusitvarkantys su psichologinèmis problemomis žmonès, pasijutę palikti likimo valiai [7]. Savižudybė dažniausiai nèra staigus vienos priežasties nulemtas veiksmas. Tai paprastai yra procesas, kurio metu žmogus išgyvena vis didejjantị stresą, emocinị skausmą, jausmų ir minčių sumaištį, o jo gebejjimas įveikti krizę vis mažeja. Ši procesą dažniausiai užbaigia paskutinis lašas - koks nors įvykis ilgoje nesėkmių, stresinių ịvykių grandinèje. Šio kritinio ịvykio negalima laikyti savižudybès priežastimi [10].

Prancūzų sociologas E. Durkheimas analizavo savižu- dybių statistiką ir nustate, jog kad ir kokie ịvairūs ir nenesikartojantys būtų savižudžių motyvai, bet savižudžių skaičius, jo augimo ir mažèjimo bendros tendencijos kiekvienoje šalyje kartojasi ir kinta, veikiamos išimtinai socialinių veiksnių [11]. Nustatyta, kad Lietuvoje, kaip ir visoje Europoje, didesnę savižudybės riziką turèjo miesto gyventojai, o su amžiumi didèja lyčių ir savižudybių asimetrija $[12,13]$. Lietuvos mokslininkų atliktas tyrimas parode, kad Lietuvoje vyresniojo mokyklinio amžiaus (15-19 m.) vaikai ir jaunuoliai žudėsi beveik 8 kartus dažniau nei jaunesniojo mokyklinio amžiaus (5-14 m.) vaikai ir paaugliai [14].

Savižudybių teorijos. İvairios savižudybès teorijos siūlo skirtingas hipotezes, kodèl žmonès bando nusižudyti. E. Šneidmano 1993 m. pasiūlyta savižudybès teorija pabrèžia psichologinį (t. y. emocinį ar psichologinị) skausmą kaip pagrindinį savižudybès bandymo motyvą. Autorius teigia, kad savižudybės griebiamasi tuomet, kai viršijamas asmens toleruotinas psichologinio skausmo slenkstis. R. Baumeister pristatė savižudybės teoriją, kuri yra pagricsta kognityvinèmis, socialinèmis ir asmenybinemis psichologinèmis konstrukcijomis. Mokslininko sukurta pabėgimo teorija skelbia, kad daugelis bandymų žudytis yra motyvuojami būtinybe sumažinti aversyvią savimonę. T. Džoinerio 2005 m. pateikta tarpasmeninè teorija teigia, kad dvi sferos - suvokiama našta ir sutrikusios priklausomybès - sąveikauja kartu, iš ko kyla savižudybès noras. Kitos teorijos išryškina beviltiškumo, problemų sprendimo, impulsyvumo ir tarpasmeninio bendravimo vaidmenis, kurie yra motyvuojantys savižudybès veiksniai [15]. Nè viena iš šių teorijų neapibrėžia savižudybės kaip kompleksinio darinio, tačiau kiekviena yra kuo nors naudinga, siekiant ją pažinti [16]. Mokslininkų teigimu, žmogaus psichinè sveikata, jị supanti mikrosocialinė aplinka, įvairūs sociokultūriniai veiksniai yra vieni iš svarbiausių veiksnių, susijusių su savižudybėmis [17]. Dèl šių priežasčių savižudybė yra labiau susijusi su potencialia (ne faktine) etiologija [18]. Nors savižudybių problemos vertinimas sulauké ženklių modifikacijų, tačiau iki šiol trūksta pakankamo šio reiškinio paaiškinimo [19]. Pastaruoju metu nagrinejjamos ịvairios aplinkos, psichologinių, biologinių veiksnių ir savižudiškų minčių bei elgesio koreliacijos. Ypatingas dėmesys skiriamas longitudiniams tyrimams, kurie labiausiai tinka nustatyti rizikos veiksnius. Tyrimai dažniausiai organizuojami pagal jų įrodomumo laipsni, t. y. pagal tai, kurie yra labiau priimtini perspektyvinèse studijose ir daugiamatèse analizėse, atitinkančiose tvirtus ịrodymus (demonstruoja unikalų poveikị vẻlesnèms savižudiškoms mintims ir elgesiui) [18].

E. Durkheimas buvo pirmasis sociologas, kuris jau XVIII amžiuje konceptualizavo savižudybę kaip socialinį reiškinị ir savižudybès priežastis siejo su socialiniais veiksniais ir procesais. Anot jo, asmenys, kurie yra nepakankamai „,integruoti“ “ $i$ visuomenę, turi didesnę savižudybės riziką, nes yra mažiau pajēgūs atlaikyti nepageidaujamų îvykių poveikị [20].

Tačiau nepaisant intensyvių tyrimų, nèra visuotinai pripažintos vienos ,savižudybès teorijos“. Atliktuose moksliniuose tyrimuose buvo nagrinètos aplinkos ir savižudiškų minčių bei elgesio rizikos veiksnių koreliacijos tarp vaikų ir jaunimo. Nustatyta, kad ankstyvame amžiuje, kai su vaiku buvo elgiamasi netinkamai, naudotos kitos netradicinès tarpusavio viktimizacijos formos (pvz., kibernetinès patyčios), 
interneto įtaka gali paskatinti jaunų asmenų savižudiškas mintis ar elgesį. Viktimizacija - stiprus jaunimo savižudybių ir rizikingo elgesio veiksnys. Patyčios sukelia sąmoningai žalingą ar nerimą keliantį elgesị. Longitudiniai tyrimai atskleide, kad socialinè atskirtis, verbalinis ar fizinis smurtas bei bendraamžių prievarta vaikysteje ir / ar ankstyvojoje paauglystėje daro įtaką kilti vẻlesnėms savižudiškoms mintims, savižudybės bandymams ir pačiai savižudybei [18]. Taigi mokslininkai yra nustatę įvairius veiksnius, kurių tarpusavio sąveika didina savižudybès riziką. Tačiau būdai, kuriais šie veiksniai sąveikauja, paskatindami suicidini procesą, yra sudètingi ir dar labai mažai suprasti [21].

Savižudybių priežastys ir rizikos daugialypiškumas. Savižudybė yra socialinis, biologinis, psichologinis reiškinys, kuriam poveikị turi genetiniai, psichologiniai, šeimos, kultūriniai, tarpasmeniniai, loginiai, filosofiniai-egzistenciniai veiksniai. Jaunų žmonių savižudybès yra sudètingos ịvairių veiksnių sąveikos pasekmė ir galutinis produktas [22-25]. Mokslinès literatūros analizè atskleidè, jog jaunų žmonių savižudybių priežasčių ir rizikos veiksnių gali būti daug ir ìvairių. Dažniausiai išskiriamos šios priežastys ir rizikos veiksniai:

- socialiniai veiksniai - šeima; veiklos praradimas, nesėkmès; smurtas; tradicijos, sociokultūrinès nuostatos; alkoholis, narkotikai, kitos psichiką veikiančios medžiagos;

- asmeniniai psichologiniai ir sveikatos veiksniai - asmenybės bruožai ir elgesio ypatumai; somatinès ligos; psichikos sutrikimai; depresija; ankstesni mėginimai žudytis [26].Tarp minètų savižudybių priežasčių ir rizikos veiksnių pažymètinas ir internetas, kaip svarbus šiandieninès jaunų žmonių savižudybių rizikos veiksnys. Interneto socialiniai tinklai gali paskatinti savęs žalojimo elgesị ir prisidèti prie to, kad vartotojai gauna neigiamų pranešimų, skatinančių žaloti save, imituojant kitų savižalingą elgesį. Moksliniais tyrimais nustatyta, jog ilgesnis laikas, praleistas socialinių tinklų svetainèse, buvo susijęs su didesniu psichologiniu susirūpinimu, nepakankamu psichikos sveikatos pagalbos poreikiu, prastu savęs vertinimu ir padažnejusiomis mintimis apie savižudybę [27].B. Mars, J. Heron ir kt. (2015) atskleidè, kad interneto informacijos, susijusios su savižudybėmis ar savęs žalojimu, naudojimas dažniau paplitęs tarp jaunų žmonių, ypač tarp asmenų, turinčių suicidinių minčių ar polinkị ị savižudybę. Tyrimais nustatyta reikšminga koreliacija tarp patologinio interneto naudojimo ir savižudiškų minčių bei savęs žalojimo $[28,29]$. Save žalojantys jaunuoliai yra aktyvesni interneto socialiniuose tinkluose nei jaunuoliai, kurie yra mažiau aktyvūs bei mažiau savarankiški. Interneto socialiniai tinklai gali tureti neigiamos įtakos apgalvotam savęs žalojimui ir paauglių savižudybėms [27].

Mokslininkai ištyrè, kad kai kuriose interneto svetainèse yra aiškiai aptariami savižudybių metodai ir joms reikalingos priemonès, o kai kuriais atvejais vartotojai net skatinami mėginti nusižudyti [30]. Irodyta, kad kibernetinès patyčios yra susijusios su savižudiškomis mintimis ar elgesiu. Gera psichikos sveikata suteikia atsparumą savižudiškiems ketinimams, todèl reikètų $i$ tai atsižvelgti, kuriant klinikines ir prevencines jauniems žmonèms skirtas programas [31]. Mokslinèje literatūroje išskiriami aplinkos veiksniai, tokie kaip aplinkos oro temperatūra, aukštis ir krituliai, kurie siejami su mirtimis dèl tyčinių sužalojimų. Atliktas tyrimas, kuris susiejo didejjančią aplinkos oro temperatūrą su didesniais savižudybių rodikliais, smurtu ir traumomis [32]. Tas pats tyrimas atskleidè teigiamą koreliacinị ryšị tarp aukščio ir savižudybių rodiklių. Nustatyta, kad egzistuoja neigiamas aukščio poveikis psichologinei nuotaikai (dirglumui, priešiškumui ir depresijai) bei pažinimo funkcijai (psichiniams igūdžiams, reakcijos laikui, psichomotoriniam veikimui, atminčiai ir kt.) [32]. Moksliniai tyrimai atskleidè ryšį tarp jaunimo bandymų žudytis ir klimato pokyčių (ypač temperatūros ir sezoninių). Manoma, kad turètų būti skiriama daugiau dèmesio moksliniams tyrimams apie sezoninių pokyčių ir klimato veiksnių įtaką jaunų žmonių savižudybėms, siekiant suvokti biopsichosocialinius mechanizmus, kurie atlieka svarbų vaidmenị ketinant nusižudyti [33].

Savižudybių prevencijos potencialas. Keletas jaunimui skirtų prevencinių priemonių parode jų naudingumą, o aukšti jaunimo savižudybių rodikliai reikalauja skubių, suderintų pastangų kuriant ir igyvendinant veiksmingas prevencijos strategijas [34]. Planuojant ateities mokslinius tyrimus, reikètų ieškoti intervencijų, kurios būtų priimtinos ir prieinamos jauniems žmonèms, ypač jauniems vyrams [35].

Nors buvo nustatytas didelis paauglių savižudybių skaičius Europoje, dauguma bandžiusių žudytis paauglių nurodè ribotą pagalbos siekị. Veiksminga savižudybių prevencija yra visapusiška, kai derinamos skirtingų sričių ir individų pastangos, kas padeda spręsti problemą îvairiais aspektais. Taigi yra būtina kompleksinè (sistemiška) pagalba kiekvienam individui, susidūrusiam su savižudybès rizika [36]. Prevencinès intervencijos gali būti dar klasifikuojamos kaip „universalios“ (skirtos visai populiacijai), ,selektyviosios“" (nukreiptos ị didesnès rizikos grupes) ir „kryptingos“ (apsaugančios asmenis) [37]. Savęs žalojimosi ir savižudybių prevencijai reikalingos tiek visuotinès priemonès, skirtos jaunimui, tiek tikslinès iniciatyvos, orientuotos ị didelès rizikos asmenų grupes [25].Norint veiksmingai kovoti su savižudybių problema, būtina pagerinti ir savižudybių stebėseną. Tarpvalstybiniai savižudybių modelių skirtumai, savižudybių rodiklių, ypatumų ir metodų pasikeitimai rodo, kad kiekviena šalis turi pagerinti su savižudybe susijusių duomenų išsamumą, kokybę ir savalaikiškumą. Tai apima 
gyvybiškai svarbią savižudybių registraciją bei nacionalinius reprezentacinius tyrimus, kuriuos atliekant renkama informacija apie bandymus nusižudyti [38].

Socialinè žiniasklaida ir savižudybių prevencija. Nors tam tikra elgsena internete gali pakenkti, skatindama savižalingą elgesị, iš kitos pusès - internetas gali būti panaudojamas savižudybių prevencijai (pvz., palaikymui ištikus krizei, socialinès izoliacijos mažinimui ar informavimui apie ją ir kt.). Jauni žmonès, dažniausiai besinaudojantys socialine žiniasklaida, nori perduoti informaciją ar pasidalinti savo nelaime su kitais asmenimis, ypač bendraamžiais. Specialios priemonès, tokios kaip socialinè žiniasklaida ar dalijimasis vaizdo įrašais, gali būti panaudojamos kaip terapinès. Klinicistai, dirbantys su jaunais save žalojančiais ar turinčiais psichikos sveikatos problemų asmenimis, turètų aktyviau diskutuoti apie naudojimosi internetu galimybes [39]. J. Robinson ir kt. (2018) teigimu, „Chatsafe“ yra pirmasis projektas, skirtas parengti ịrodymais pagristas gaires, kurios padètų jaunam žmogui saugiai kalbèti apie savižudybę socialinèje erdvèje [40].

Savižudybių prevencijos strategijos. Pasaulio psichikos sveikatos veiksmų plane, skirtame 2013-2020 m., nurodoma, kad svarbu igyvendinti psichikos sveikatos stiprinimo ir prevencijos strategijas, kuriose vienas iš pagrindinių veiksmu yra savižudybių prevencija. Siekiant sumažinti savižudybių skaičių, reikia kurti ir ịgyvendinti išsamias nacionalines strategijas, kurios padètų išvengti savižudybių, ypač didelị dèmesị skiriant padidejjusios rizikos grupèms, įskaitant ir jaunimą [41]. Vis dažniau pripažistama, kad dotacijos vaikystès laikotarpiu bei galimybės naudotis paslaugomis turi tapti viešosios politikos dèmesio centru. Pasaulio sveikatos organizacija savižudybių prevencijai pateikia bendruomenès ịtraukimo ịrankių rinkinị, kuriame išryškinti šie pagrindiniai savižudybių skaičiaus mažinimo etapai: pradinis pasirengimas, pokalbio užmezgimas per pirmajį susitikimą, bendruomenès veiksmų plano sukūrimas, žiniasklaidos mobilizacija, bendruomenès veiksmų plano stebejjimas ir vertinimas bei bendruomenès susitikimas [38]. Siekiant mažinti savižudybiu riziką, galima pasitelkti sumaniosios edukacijos igalinimo modeli, kuris yra grindžiamas ir apibūdinamas vadinamaisiais 3D principais: daugiafunkcinis, daugiakriterinis ir daugiasektorinis. Šie principai padeda igalinti asmenis, socialines grupes, didina įtrauktị, kūrybiškumą, inovacijas ir teikia į bendruomenę orientuotas, universaliuoju dizainu pagrịstas kompleksines paslaugas [36]. Tarptautinis Rotary projektas (angl. Rotary International Global Grant Project) „Savižudybių prevencijos modelis ir jo taikymas Lietuvos savivaldybėse - SUPREME AIM“ yra viena iš svarbiausių ilgalaikių tarptautinių Rotary rajonų savižudybių prevencijos programų (veikianti nuo 2014 m.), kurios tikslas yra sukurti sistemini požiūrị i savižudybių prevenciją ir sukurti tvaraus proceso platformą. Projekto „Internetinių patyčių prevencija, sukuriant sąmoningą internetinę bendruomenę" (angl. Address Cyberbullying By Creating a Conscious Online Community) tikslas yra sukurti priemonę, kuri spręstų patyčių internete problemą ir kurtų saugesnę aplinką socialiai pažeidžiamiems vaikams ir jaunimui. Šis projektas netiesiogiai prisideda ir prie savižudybių prevencijos veiklų. Taigi jaunimo savižudybių problemai spręsti turi būti kuriamos veiksnios strategijos, nuosekliai taikomos prevencinès priemonès, programos ir projektai bei nuolat skiriama pakankamai dèmesio šiam fenomenui. Anot Aukštuolytès (2013), , , ..> gyventi ar negyventi renkasi pats žmogus. Tačiau specialistų, politikų ir valstybès tarnautojų rūpesčiu ištiesta pagalbos ranka padètų jam pasirinkti gyvenimą, o ne mirtį““ [7]. Visuomenès informavimas, mokymas, švietimas apie savižudybės fenomeną prisideda mažinant stigmatizavimą, vykdant prevencinę savižudybių veiklą bei mažinant mirtingumą nuo savižudybių.

\section{Išvados}

Savižudybės yra viena pagrindinių jaunų žmonių mirties priežasčių pasaulyje. Savižudybe - tai ne liga, o desperatiškas jauno žmogaus, neradusio kitos išeities, poelgis. Savižudybė dažniausiai nèra staigus vienos priežasties nulemtas veiksmas. Tai paprastai yra procesas, kurio metu žmogus išgyvena vis didejjantị stresą, emocinị skausmą, jausmų ir minčių sumaištị, o jo gebejjimas įveikti krizę vis mažejja. Ši procesą paprastai užbaigia koks nors ịvykis ilgoje nesėkmių, stresinių ịvykių grandineje. Jaunų žmonių savižudybių priežastys ir rizikos veiksniai gali būti ịvairūs - socialiniai, asmeniniai psichologiniai, sveikatos ir kt. Pastaruoju metu virtuali erdvé bei interneto socialiniai tinklai tampa aktualiu jaunų žmonių savižudybių rizikos veiksniu.Jaunų žmonių savižudybės yra viena iš pagrindinių problemų, kurią spręsti reikia taikant efektyvias prevencines priemones. Visuomenès informuotumo didinimas, savižudybės tabu laužymas ir švietimas apie vyraujančius mitus galètų padèti užkirsti kelią šiai tyčinei savinaikai. Visuomenei reikètu pateikti daugiau informacijos, kaip atpažinti galimą savižudišką elgesị ir interpretuoti suicidinių minčių turinčio jaunuolio siunčiamus pagalbos ieškojimo, siekiamo palaikymo, žinios skleidimo ženklus. Svarbu kurti ir igyvendinti išsamias nacionalines strategijas, kurios padètų išvengti jaunimo savižudybių. Psichikos sveikatos stiprinimo programų ịgyvendinimas ir savalaikès pagalbos paslaugų vaikysteje prieinamumo didinimas turi tapti prioritetine sveikatos politikos sritimi.

\section{Literatūra}

1. Lygnugarytė-Grikšienė A., Leskauskas D., Jasinskas N., Ma- 
siukiene A. Factors influencing the suicide intervention skills of emergency medical services providers. Medical Education Online 2017;22(1):1291869.

https://doi.org/10.1080/10872981.2017.1291869

2. Barta MM. Silence on the endemic suicides in Lithuania: background, causes, and prospective solutions. Honors Thesis and Capstone Projects. Dominican University of California (San Rafael, California). 2017.

3. Preventing suicide: a global imperative. WHO (Geneva). 2014.

4. Stein DJ, Chiu WT, Hwang I, Kessler RC, Sampson N, Alonso J. et al. Cross-national analysis of the associations between traumatic events and suicidal behavior: findings from the WHO World Mental Health Surveys. Plos One 2010;5(5):1-13. https://doi.org/10.1371/journal.pone.0010574

5. Horton R. Suicide prevention: steps to be taken. The Lancet 2012;379(9834):2314.

https://doi.org/10.1016/S0140-6736(12)61000-9

6. Gailienė D. Gyvenimas po lūžio. Kultūrinių traumų psichologiniai padariniai. Vilnius. 2015.

7. Aukštuolytė N. Savižudybė kaip žmogaus apsisprendimo aktas ir ji sąlygojantys veiksniai. Visuomenès saugumas ir viešoji tvarka, 2013;9:34-44.

8. Adamou M, Antoniou G, Greasidou E et al. Toward automatic risk assessment to support suicide prevention. Crisis 2019;40(4):249-256. https://doi.org/10.1027/0227-5910/a000561

9. Lewiecki EM, Miller SA. Suicide affects all of us. The Lancet 2012;379(9834):2316-2318.

https://doi.org/10.1016/S0140-6736(12)60726-0

10. Pivorienė R. V., Sturlienė N., Auškelis R. Savižudybių prevencija mokykloje. Metodinès rekomendacijos socialiniams pedagogams. Švietimo aprūpinimo centras (Vilnius). 2004.

11. Čigrin V. Deviantinis elgesys kaip socialinè deviacija. Visuomenès saugumas ir viešoji tvarka, 2012;8:76-96.

12. Navickas A., Smirinenko A., Navickas P., Lukavičiūtè L., Dembinskas A., Gurevičius R., Aliukonienė R., Benošis A., Badaras R., Daškevičius K., Daškevičienė J. Savižudybių mediciniški ir visuomeniški aspektai Lietuvoje XX amžiaus pirmojoje pusejje. Sveikatos mokslai, 2016;26(1):88-95.

https://doi.org/10.5200/sm-hs.2016.014

13. Soole R, Kõlves K, De Leo D. Suicide in children: a systematic review. Archives of Suicide Research: Official Journal of the International Academy for Suicide Research 2015;19(3):285-304. https://doi.org/10.1080/13811118.2014.996694

14. Lekečinskaitė L., Lesinskienė S. Vaikų ir jaunimo iki $20 \mathrm{~m}$. savižudybès Lietuvoje 2010-2015 m. Visuomenès sveikata, 2017;2(77):74-80.

15. Klonsky D, May AM, Saffer BY. Suicide, suicide attempts, and suicidal ideation. Annual Review of Clinical Psychology 2016;12:307-30.

https://doi.org/10.1146/annurev-clinpsy-021815-093204
16. Jankauskas J. P. Sveikos gyvensenos pagrindai. VU leidykla (Vilnius). 2015.

17. Benošis A., Aliukonienė R., Navickas A., Aliukonis V. Savižudybių prevencijos aktualijos ikiteisminių tyrimų medžiagos apžvalgos duomenimis. Sveikatos mokslai, 2016;26(1):10-20. https://doi.org/10.5200/sm-hs.2016.002

18. Cha CB, Franz PJ, Guzmán EM, Glenn CR, Kleiman EM, Nock MK. Annual research review: suicide among youth - epidemiology, (potential) etiology, and treatment. The Journal of Child Psychology and Psychiatry 2018;59(4):460-482.

https://doi.org/10.1111/jcpp.12831

19. Majchrzyk Z, Wiszniowska-Majchrzyk M. Suicides - the permanence of motives. Sveikatos mokslai, 2016;26(1):117-122. https://doi.org/10.5200/sm-hs.2016.015

20. Sara GE. Mental disorder and suicide: a faulty connection, or a faulty argument? Australian and New Zealand Journal of Psychiatry 2015;49(1):84-86. https://doi.org/10.1177/0004867414553953

21. Dadašev S. Mèginusiųjų nusižudyti savižudybės proceso patirtis. Daktaro disertacija. Vilnius. 2017.

22. Leonavičius R., Valius L. Šeimos gydytojo vaidmuo savižudybių prevencijoje. Kaunas. 2017.

23. Laskytè, A. Lietuvos moksleivių sąmoningo savęs žalojimo epidemiologija. Psichologiniai tyrimai Lietuvoje: vieta pasaulyje ir ateities vizija. Straipsnių rinkinys. Sud. E. Kazlauskas. VU leidykla (Vilnius). 2007.

24. Hawton K, Saunders KE, O'Connor RC. Self-harm and suicide in adolescents. The Lancet 2012;379(9834):2373-2382. https://doi.org/10.1016/S0140-6736(12)60322-5

25. Zaborskis A., Sirvyte D., Zemaitiene, N. Prevalence and familial predictors of suicidal behaviour among adolescents in Lithuania: a cross-sectional survey 2014. BMC Public Health 2016;16:554.

https://doi.org/10.1186/s12889-016-3211-x

26. Jaunimo psichinè sveikata ir savižudybès. Švietimo problemos analizè. ŠMM (Vilnius). 2013;2(88).

27. Memon AM, Sharma SG, Mohite SS, Jain S. The role of online social networking on deliberate self-harm and suicidality in adolescents: a systematic review of literature. Indian Journal of Psychiatry 2018;60(4):384-392.

28. Mars B, Heron J, Biddle L, Donovan JL, Holley R, Piper M, Potokar J, Wyllie C, Gunnell D. Exposure to, and searching for, information about suicide and self-harm on the internet: prevalence and predictors in a population based cohort of young adults. Journal of Affective Disorders 2015;185:239-245. https://doi.org/10.1016/j.jad.2015.06.001

29. Durkee T, Hadlaczky G, Westerlund M, Carli V. Internet pathways in suicidality: a review of the evidence. International Journal of Environmental Research and Public Health 2011;8(10):3938-3952.

https://doi.org/10.3390/ijerph8103938 
30. Sakarya D, Güneş C, Sakarya A. Googling suicide: evaluation of websites according to the content associated with suicide. Turkish Journal of Psychiatry 2012;1-4. https://doi.org/10.5080/u6870

31. Brailovskaia J, Teismann T, Margraf J. Cyberbullying, positive mental health and suicide ideation/behavior. Psychiatry Research 2018;267:240-242.

https://doi.org/10.1016/j.psychres.2018.05.074

32. Merrill R. Injury-related deaths according to environmental, demographic, and lifestyle factors. Journal of Environmental and Public Health 2019;1-12.

https://doi.org/10.1155/2019/6942787

33. Akkaya K, Vyssoki B, Winkler D, Willeit M, Kapusta ND, Dorffner G, Özlü-Erkilic Z. The effect of seasonal changes and climatic factors on suicide attempts of young people. Psychiatry 2017; $15 ; 17(1): 365$. https://doi.org/10.1186/s12888-017-1532-7

34. King CA, Arango A, Foster CE. Emerging trends in adolescent suicide prevention research. Current Opinion in Psychology 2018;22:89-94.

https://doi.org/10.1016/j.copsyc.2017.08.037

35. Cotter P, Kaess M, Corcoran P, Parzer P, Brunner R, Keeley H et al. Help-seeking behaviour following school-based screening for current suicidality among European adolescents. Social Psychiatry and Psychiatric Epidemiology 2015;50:973-982. https://doi.org/10.1007/s00127-015-1016-3

36. Celiešienė E., Kvieskienė G. Sumaniosios edukacijos ịgalinimas mažinant savižudybių rizikas. Socialinis ugdymas / Aktyvi įtrauktis, 2017;47(3):190-203. https://doi.org/10.15823/su.2017.30

37. Large MM. The role of prediction in suicide prevention. Dialogues in Clinical Neuroscience 2018;20(3):197-205.

38. Suicide. WHO (Geneva). 2018.

39. Marchant A, Hawton K, Stewart A, Montgomery P, Singaravelu V, Lloyd K, Purdy N, Daine K, John A. A systematic review of the relationship between internet use, self-harm and suicidal behaviour in young people: the good, the bad and the unknown. PLoS One 2017;13(3):e0193937. https://doi.org/10.1371/journal.pone.0193937

40. Robinson J The \#chatsafe project. Developing guidelines to help young people communicate safely about suicide on social media: a Delphi study. PLoS One 2018;13(11):e0206584.

https://doi.org/10.1371/journal.pone.0206584

41. Mental health action plan 2013-2020. WHO (Geneva). 2013.

\section{THE DISCOURSE OF SUICIDE PHENOMENON} IN YOUNG PEOPLE

B.Strukčinskienė, D.Tervydytė, V.Strukčinskaitė, N.Strazdienė, E.Griškonytė, S.Griškonis

Keywords: suicide, phenomenon, young people, youth.

Summary

Lithuania has been one of the suicide leaders in Europe and in the world for several years. Suicide is one of the main causes of death in young people globally. Young people face many challenges that lead to changes in their behavior. The aim of the study was to analyze the suicide phenomenon in young people. A systematic review and analysis of scientific literature and documents were applied.

Suicide is not a disease, but a desperate act of a young person who thinks there is no other way. Suicide is usually not a sudden act having a one cause, but a consequence of a process. A person experiences increasing stress, emotional pain, confusion of feelings and thoughts, so his ability to overcome a crisis is decreasing in this process. The pick of this process is usually some event in a long chain of failures and stressful events. Causes and risk factors of suicide in young people can be various, e.g. social, personal psychological, health, etc. Recently virtual space and online social networks have become an important risk factors of suicide in young people.

Suicide in young people is one of the main problems to be addressed using effective preventive measures. Raising public awareness, breaking the taboos of suicide, and educating on prevailing myths could help prevent these intentional self-injuries. The public should be given more information on how to recognize possible suicidal behavior and interpret the signs sent by a young person overwhelmed with suicidal thoughts, i.e. signs of seeking help and support. It is important to develop and implement comprehensive national strategies to prevent youth suicide. Implementing mental health promotion programs and increasing access to care services in early childhood must become a priority in health policy.

Correspondence to: birutedoctor@hotmail.com

Gauta 2019-08-23 